для управління процесом формування готовності майбутніх учителів географії до профільного навчання старшокласників, забезпечує його якість, гнучкість, цілеспрямованість та створює передумови підвищення рівня означеної готовності у студентів, майбутніх фахівців.

Водночас необхідно зауважити, що окремі аспекти цієї важливої проблеми ще потребують вивчення. Аналіз практики показує, що нині у вищих навчальних закладах організовується й проводиться моніторинг в основному якості навчальновиховного процесу й результатів (працевлаштування випускників тощо). На жаль, майже відсутні моніторингові дослідження умов організації діяльності вищого навчального закладу, немає досліджень, об'єктом яких $\epsilon$ рівень управління навчальним закладом, якість ресурсів, інформаційно-освітнього середовища тощо.

Поза увагою під час організації моніторингу якості освіти залишається дослідження зовнішніх упливів на діяльність вищого навчального закладу: аналіз ринку праці, освітні потреби учасників навчально-виховного процесу, розвиток системи освітніх послуг.

На рівні навчального закладу не досліджуються такі питання, як відстеження ефективності напрямів стратегічного розвитку навчального закладу, систематичність та грунтовність налагодження зовнішніх і внутрішніх зв'язків із соціальними установами, відстеження політики якості й стратегії розвитку навчального закладу, розвиток кадрової політики (безперервність навчання педагогічних працівників), управління фінансовими, матеріальними ресурсами, іміджеві аспекти діяльності навчального закладу. I головне, на наш погляд, це те, що немає цілеспрямованого, безперервного відстеження професійно важливих особистісних характеристик, що детермінують професійне становлення студента, а також параметри оцінювання їх професійного розвитку.

\title{
Література
}

1. Сльникова Г. В. Наукові основи розвитку управління загальною середньою освітою в регіоні : [монографія] / Г. В. Єльникова. - К. : ДАККО, 1999. - 303 с. 2. Майоров А. Н. Мониторинг в системе информационного обеспечения управления образованием : автореф. дис. на соискание уч. степени докт. пед. наук.: спец. 13.00.01. «Общая педагогика. История педагогики и образования» / А. Н. Майоров. - СанктПетербург, 2003. - 45 с. 3. Моніторинг якості освіти: становлення та розвиток в Україні: Рекомендації з освітньої політики / за заг. ред. О. І. Локшиної. - К. : К.І.С., 2004. - 160 с. 4. Чандра М. Ю. Системный мониторинг как средство управления качеством образовательного процесса: дис. ... канд. пед. наук: 13.00.08/ Чандра Маргарита Юрьевна. - Волгоград, 2008. - 203 с.

УДК $316.61: 37.03$

Світлана Матвійчина

\section{ФОРМУВАННЯ ІНТЕРАКТИВНОГО СОЦІОКУЛЬТУРНОГО СЕРЕДОВИЩА ЯК ДИДАКТИЧНА УМОВА САМОРОЗВИТКУ ОСОБИСТОСТІ СТУДЕНТІВ КОЛЕДЖІВ}

Матвійчина С. В. Формування інтерактивного соціокультурного середовища як дидактична умова саморозвитку особистості студентів коледжів.

Статтю присвячено дослідженню сутності наукових категорій «соціокультурне середовище» та «інтерактивне соціокультурне середовище». Проаналізовано основні підходи до змісту зазначених наукових дефініцій. Здійснено аналіз їх сутності з точки зору психології та педагогіки. Основну увагу зосереджено на аналізі підходів науковців до змісту, який вони вкладають у трактування інтерактивного соціокультурного середовища як вагомої дидактичної умови, що суттєво впливає на 
стимулювання саморозвитку особистості студентів, які навчаються в коледжах.

Ключові слова: соціальне середовище, інтерактивне соціокультурне середовище, саморозвиток, студенти коледжу.

Матвийчина С. В. Формирование интерактивной социокультурной среды как дидактическое условие саморазвития личности студентов колледжей.

Статья посвящена исследованию сущности научных категорий «социокультурная среда» и «интерактивная социокультурная среда». Проанализированы основные подходы к содержанию указанных научных дефиниций. Проведен анализ их сущности с точки зрения психологии и педагогики. Основное внимание сосредоточено на анализе подходов ученых к содержанию, которое они вкладывают в трактовку интерактивной социокультурной среды как весомого дидактического условия, что существенно влияет на стимулирование саморазвития личности студентов, обучающихся в колледжах.

Ключевые слова: социальная среда, интерактивная социокультурная среда, саморазвитие, студенты колледжа.

Matviychyna S. V. Formation of interactive didactic socio-cultural environment as a condition of self-identity students of colleges

The article investigates the nature of scientific categories of «socio-cultural environment» and «interactive socio-cultural environment». The main approaches to the content of these scientific definitions. The analysis of the essence in terms of psychology and pedagogy. The main focus is on the analysis of scientific approaches to the content that they put in the interactive interpretation of socio-cultural environment as an important didactic terms, which has a significant impact on stimulating self-identity of students enrolled in colleges.

Key words:social environment, socio-cultural environment of interactive, selfdevelopment, student of colleges.

Нині в якісно новому ракурсі постає проблема реалізації навчально-виховних пріоритетів під час підготовки майбутніх фахівців, які здобувають освіту у вищих навчальних закладах I-II рівнів акредитації. Першочергового розв'язання потребують питання професійної конкурентоспроможності майбутніх фахівців 3 освітньокваліфікаційним рівнем «молодший спеціаліст». 3 огляду на зазначене переосмислення потребують теоретико-практичні підходи до формування у студентів коледжів готовності до саморозвитку. Вагомою перспективою щодо вдосконалення саморозвитку студентів фінансово-економічних коледжів відіграє інтерактивне соціокультурне середовище, яке водночас $є$ вагомою дидактичною умовою.

Аналіз останніх досліджень і публікацій свідчить про те, що питання вдосконалення інтерактивного соціокультурного середовища в останні роки часто розглядалося в науковій літературі. Багато дослідників під час вивчення соціокультурного середовища тієї чи тієї установи застосовують теорію систем, відзначаючи при цьому, що людина - це складна, відкрита, саморозвинена система. 3 точки зору системного підходу заслуговує на увагу теорія «синергетики», автори якої роблять акцент на самоорганізації та саморегуляції соціокультурного середовища. На думку науковцівсинергетиків, соціокультурне середовище постійно активно впливає на розвиток особистості та передбачає інформаційно-енергетичну відкритість і активність за рахунок постійної взаємодії з іншою системою або зовнішнім середовищем.

У дослідженнях Ю. Кулюткіна та С. Тарасова соціокультурне середовище складається із кількох взаємопов'язаних рівнів, а саме глобального, регіонального та 
локального. Зокрема глобальний рівень охоплює загальносвітові тенденції розвитку світової культури, економіки, політики, освіти, а також глобально-інформаційну мережу. До регіонального рівня відносять освітню політику, культуру, систему освіти конкретної країни. Цей рівень передбачає й національні норми, звичаї і традиції, які існують у конкретному регіоні певної країни. До локального рівня належить мікрокультура та мікроклімат конкретної освітньої установи, сюди відносять і найближче оточення, зокрема сім'ю, що мають вагомий уплив на становлення особистості.

Аналіз сучасних наукових досліджень дозволяє стверджувати, що на сучасному етапі серед науковців відсутнє єдине розуміння парадигми соціокультурного середовища, що пояснюється насамперед багатовимірністю, поліфункціональністю і варіативністю. Загалом дослідники в узагальненому вигляді під соціокультурним середовищем розуміють систему ключових чинників, що визначають розвиток людини. Безпосередньо до складників соціокультурного середовища відносять: природне середовище, суспільно-політичний лад, засоби масової інформації, навчальні заклади, заклади культури, видатних постатей, які впливають на культурні й освітні процеси, а також випадкові події.

У вітчизняній педагогічній науці простежуються тісні взаємозв'язки між організацією навчально-виховного процесу у сприятливому соціокультурному середовищі та його результативністю. Такий підхід представлено в наукових дослідженнях Н. Селіванової та В. Сухомлинського. Причому соціальне середовище розглядається як вагомий чинник становлення особистості, що має вплив на формування інтересів, мотивів, цілей, здібностей та загальної активності майбутнього фахівця.

Орієнтація української освітньої галузі на гуманістичні освітні цінності, які мають реалізовуватися під час здобуття студентами освітньо-кваліфікаційного рівня «молодший спеціаліст», спонукає до дослідження ролі соціокультурного середовища. Зважаючи на той факт, що питання ролі соціокультурного середовища вищих навчальних закладів I-II рівнів акредитації як дидактичної умови у процесі стимулювання саморозвитку особистості студентів не було предметом окремого наукового дослідження, ми поставили собі за мету більш глибше вивчити означене коло питань.

Отже, метою статmi $є$ дослідження можливостей інтерактивного соціокультурного середовища вищих навчальних закладах I-II рівнів акредитації у процесі вдосконалення саморозвитку молодших спеціалістів, які у цих закладах здобувають освіту.

Зазначимо, що соціальне середовище, у якому функціонує i розвивається навчальний заклад, сприймається сьогодні як один із важливих чинників ії діяльності. Науковці переконані в тому, що соціальне середовище має вагомий уплив на формування конкурентоспроможності фахівців, яких він готує, а також сприяє позитивному іміджу самого освітнього закладу. Отже, дослідження можливостей соціокультурного середовища освітнього закладу допомагає процесу розвитку й саморозвитку особистості студента.

Ми погоджуємося із В. Логвін [3] у тому, що наукова категорія «середовище» містить все те, що здійснює вплив на розвиток людини. Науковець зазначає, що починаючи із першої половини XX століття, в наукових дослідженнях середовище у своєму трактуванні наближається до розуміння його як засобу управління процесом становлення особистості дитини. До прикладу, С. Швацький уважав, що соціальне середовище - це весь педагогічний процес як складне явище соціального порядку, яке спрямовується в той чи той бік, змінюється якісно або кількісно. У подальшому 
середовище починає сприйматись не лише як об'єктивний чинник становлення особистості, а й як об'єкт управлінського та педагогічного впливів, у результаті чого воно стає засобом виховання. Таку думку підтримував Л. Виготський, який уважав, що вчитель $є$ організатором і управителем соціального виховного середовища. У напрацюваннях Д. Дьюї знаходимо таку цитату: «Ми виховуємо не напряму, а за допомогою середовища спеціально формуємо для цих цілей середовище».

Нині освітнє середовище розглядається як сукупність умов, що впливають на розвиток і формування здібностей, потреб, інтересів, свідомості особистості, яка навчається в освітньому закладі. При цьому основним критерієм визначення освітнього середовища є взаємодія. Наприклад, Л. Новікова вважає, що середовищем $\epsilon$ та частина навколишнього світу, 3 якою суб'єкт взаємодіє [5, с. 3-4]. Освітнє середовище, у трактуванні В. Ясвіна, - це «сукупність упливів й умов формування особистості, а також можливостей для іiі розвитку, що містяться в іiі оточенні» [7, с. 11]. Ключовий момент наведеного визначення освітнього середовища - це поняття «можливості», що підкреслює активний характер особистості, яка освоює це освітнє середовище, а також взаємний характер впливу як особистості на освітнє середовище, так і середовища на особистість.

У сучасній науковій літературі соціокультурне середовище визначається як конкретний вияв суспільних відносин, у яких розвивається конкретна особистість. За умови відповідних дій з боку освітньої організації соціальне середовище може стати важливим ресурсом іiі розвитку. Здійснення таких упливів задля педагогізації середовища містить цілеспрямовану педагогічну активність, що сприяє формуванню у студентів соціальнозначущих цінностей і потреб соціального характеру. Л. Новікова [5] зазначає, що створення такого соціокультурного середовища передбачає, перш за все, системно організовані педагогічні впливи. При цьому зусилля педагогічного колективу мають бути спрямовані не на ліквідацію середовища неорганізованого, а на внесення його в якості складника в систему соціокультурного середовища.

На основі напрацювань фахівців $[1 ; 2 ; 6]$ установлено, що за своїм соціальним призначенням соціокультурне середовище освітнього закладу має відповідати трьом основним вимогам:

- формувати в особистості соціально й особистісно значущі потреби та інтереси і забезпечувати умови для їх задоволення відповідно до соціальних і культурних норм;

- створювати умови для самореалізації духовних сил особистості;

- забезпечити відтворення соціокультурного потенціалу.

Безперечно, необхідно зважати на те, що кожне соціокультурне середовище освітнього закладу має свою специфіку. Тобто в кожному навчальному закладі функціонує конкретна система умов праці та побуту, існує циклічність у відтворенні професійної структури, розроблені форми спілкування і норми поведінки. Отже, соціокультурне середовище освітнього закладу ми розглядаємо як важливу дидактичну умову особистісного розвитку і становлення майбутнього фахівця, що працюватиме у фінансово-економічній сфері. У нашому баченні соціокультурне середовище вищих навчальних закладах I-II рівнів акредитації- це складний організований феномен, що поєднує в собі різні соціально значущі чинники (соціально-економічні, культурно-просвітницькі, національні, інформаційні тощо). Іншими словами, до соціокультурного середовища можна віднести усе, що оточує студента під час навчання у вищому навчальному закладі.

Соціокультурне середовище коледжів формується поступово, 3 наповненням його ідеями й цінностями, змістом та методами роботи. У результаті виникає 
унікальна атмосфера, яка активно впливати на процес розвитку й саморозвитку особистості студента. На основі аналізу напрацювань Ю. Мануйлова [4] встановлено, що для інтерактивного соціокультурного середовища властиво:

- визнання рівноцінності й гідності всіх суб'єктів навчально-виховного процесу;

- спільне активне (діяльнісне) оволодіння навколишнім світом;

- емоційне взаємосприйняття та обмін між суб'єктами взаємодії.

Зазначимо, що соціокультурне середовище містить зовнішнійі внутрішній складники. Важливим елементом використання освітнього потенціалу зовнішнього середовища є соціальне партнерство, яке спрямоване встановлення дієвих відносин освітнього закладу з іншими організаціями, що передбачає:

- чітке окреслення актуальної проблеми, іiі соціальної значущості, перспективності, можливих напрямків, шляхів і засобів іiі розв'язання, у чому зацікавлені як коледж, так і всі партнери, з якими співпрацює навчальна установа;

- закріплення й розвиток тісних зв'язків, встановлення формальних та неформальних партнерських відносин на основі взаємоповаги й довіри один до одного;

- безумовну й цілеспрямовану підтримку позитивного іміджу студентів;

- забезпечення наукових основ колегіального управління спільними проектами;

- широку рекламу успішної співпраці через підготовку й проведення науковопрактичних заходів, публікацію тематичних статей у педагогічній пресі, участь у конференціях, які спрямовані на стимулювання саморозвитку майбутніх фахівців.

Внутрішнє соціокультурне середовище $\epsilon$ сукупністю умов, які організує адміністрація, науково-педагогічний колектив, за обов'язкової участі самих студенів задля створення оптимальних умов для всебічного розвитку особистості майбутніх фахівців. Окреслена позиція знайшла відображення у психологічних дослідженнях, де таке середовище розглядається як процес й результат власного творчого саморозвитку особистості. Отже, внутрішнє середовище вищих навчальних закладів I-II рівнів акредитації розглядається нами як динамічна мережа взаємопов'язаних педагогічних подій, що створюються зусиллями соціальних суб'єктів різного рівня (колективних та індивідуальних), $є$ інтегрованою умовою розвитку особистості. Встановлено, що головним механізмом забезпечення розвитку соціокультурного середовища стає творча співпраця студентів та викладацького складу, у якому ключовим технологічним моментом є їх спільна цілеспрямована діяльність. При цьому принципово важливо, щоб студенти самі долучались до розв'язання освітніх та соціокультурних проблем шляхом вироблення власної індивідуальної освітньої траєкторії.

Отже, соціокультурне середовище вищих навчальних закладів I-II рівнів акредитації, які готують молодших спеціалістів, що працюватимуть у фінансовоекономічній галузі, є тією основою, на якій формується інтелектуальний і духовний потенціал особистості. При цьому розвиток інтерактивного соціокультурного середовища має сприяти збільшенню потенційних можливостей життєдіяльності студентів на основі саморозвитку.

Практична діяльність викладацького складу в галузі розвитку інтерактивного соціокультурного середовища вищих навчальних закладів I-II рівнів акредитації як дидактичної умови стимулювання саморозвитку студентів, у нашому розумінні, має передбачати такі завдання:

- здійснити аналіз стану сформованості інтерактивного соціокультурного середовища освітньої установи, окреслити головні суперечності, визначити чинники, що їх породжують, та знайти конкретні засоби їх вирішення;

- інтегрувати освітні можливості інтерактивного соціокультурного середовища; 
- ввести до кола життєдіяльності освітнього закладу реальні позитивні події, що відбуваються в довкіллі, намагатись максимально пристосувати освітнє середовище до потреб студентів;

- наповнити середовище практичним змістом життєдіяльності та спілкування;

- сприяти становленню в освітньому закладі поваги й довіри до студента, створити умови для успішного розвитку його особистості (визначення, усвідомлення, удосконалення).

Фінансово-економічний коледж Буковинського державного фінансовоекономічного університету $\epsilon$ інтегративним соціокультурним простором, у якому освітня, соціально-виховна, трудова, фізкультурно-оздоровча, соціально-побутова, управлінсько-координаційна галузі взаємодіють у навчально-виховному процесі і взаємодоповнюють одна одну. I водночас у своїй сукупності становлять комплексний чинник саморозвитку майбутніх фахівців, які здобувають освітньо-кваліфікаційний рівень «молодший спеціаліст».

Нині глобальним завданням навчальних закладів I-II рівнів акредитації вважаємо підготовку висококваліфікованих фахівців, які здатні творчо мислити та оперативно розв'язувати майбутні професійні завдання на основі застосування інноваційних інформаційних технологій. Саме можливість обміну інформацією на відстані та використання потенційно необмеженого характеру й сукупності джерел інформації інтерактивним освітнім середовищем. Інтерактивне середовище науковці визначають як web-грунтовне середовище, що підтримує структуровану взаємодію між членами навчальної спільноти та забезпечує гнучкість, демократичність, відкритість, доступність, ефективність, завершеність навчально-виховного процесу. Інтерактивне освітнє середовище також передбачає вільний вибір місця, часу, змісту та форм навчання, за яких студент сам здобуватиме й конструюватиме власну професійну компетентність під час навчання.

Отже, інтерактивне соціокультурне середовище Фінансово-економічного коледжу Буковинського державного фінансово-економічного університету- це сукупність взаємопов'язаних i взаємодоповнюючих економічних, соціальних i культурних відносин щодо освіти, які дозволяють продуктивно організувати навчально-виховний процес. Саме інтерактивне соціокультурне середовище навчального закладу суттєво впливає на розвиток навичок критичного мислення, пізнавальних інтересів і творчості студентів, а також сприяє соціокультурній адаптації й соціалізації на основі формування світоглядних та ціннісних особистісних орієнтирів і внутрішньої мотивації до саморозвитку.

Студент у процесі індивідуальних бесід чи групових занять переймає у викладачів уміння самоаналізу і самооцінювання. Усе це сприяє стимулювання саморозвитку на основі цілеспрямованої та свідомої роботи над собою $з$ тим, щоб забезпечити такий рівень розвитку особистості майбутнього фахівця фінансовоекономічної галузі, який би відповідав суспільним вимогам й особистісному ідеалу. Ми переконані в тому, що фінансово-економічний коледж Буковинського державного фінансово-економічного університету - це освітній навчальний заклад I-II рівнів акредитації, у якому створено позитивне гуманістично-орієнтоване інтерактивне соціокультурне середовище для студентів, яке дозволяє їм стати повноцінними носіями загальнолюдської культури та представниками інтелектуальної еліти нашої країни у фінансовій галузі, які здатні до саморозвитку.

Досліджуючи інтерактивне соціокультурне середовище як педагогічний феномен, ми виходили 3 розуміння того, що його позитивний уплив на 
життєдіяльність і соціальну активність особистості студентів можливий лише за умови функціонування міжособистісного простору, у якому кожен майбутній фахівець буде відчувати себе комфортно в емоційному плані та стабільно у плані саморозвитку. Навчально-виховний процес у вищих навчальних закладах I-II рівнів акредитації, які готують фахівців 3 освітньо-кваліфікаційним рівнем «молодший спеціаліст»- це передусім сталий, цілеспрямований процес створення інтерактивного соціокультурного середовища, що сприяє саморозвитку та самовихованню особистості, яка усвідомлює обрану професію невід’ємним складником універсального цивілізаційно-культурного простору. Саме це детермінує мету навчально-виховної діяльності у Фінансово-економічному коледжі Буковинського державного фінансовоекономічного університету, яка полягає у формуванні національної інтелігенції, оновленні і збагаченні духовного та інтелектуального генофонду нації, що передбачає гармонійно розвинену, цілісну особистість, фундаментальними характеристиками якої $€$ духовність, культурна самоідентифікація, соціальна i професійна компетентність у фінансово-економічній галузі.

\section{Література}

1. Бітаєв В. А. Людина і соціокультурне середовище: проблема взаємоадаптації / В. А. Бітаєв// Актуальні філософські та культурологічні проблеми сучасності (альманах). - К., 2000. - С. 81-90. 2. Давиденко А.Роль соціального середовища у творчості людини / А. Давиденко // Збірник наук. праць. - К., 2004. - С. 57-61. 3. Логвін В. Л. Розвиток соціокультурного середовища освітнього закладу в системі діяльності керівника школи / В. Л. Логвін //[Електронний ресурс]. - Режим доступу: http:/virtkafedra.ucoz.ua/elgurnal/pages/vyp7 /konf3/Logvin.pdf.4. Мануйлов Ю. С.

Средовой подход в воспитании / Ю. С. Мануйлов. - [2-е изд., перераб.]. М.: Н. Новгород, 2002. - 157 с. 5. Новикова Л. И. Школа и среда / Л. И. Новикова. М. : Знание, 1985. - 80 с. 6. Пащенко Д. І. Зарубіжний досвід гуманізації соціального середовища та виховання / Д. І. Пащенко. - К. : Знання, 1999. - 208 с. 7. Ясвин В. А. Образовательная среда: от моделирования к проектированию/В. А. Ясвин. - М. : Смысл, 2001. - 365 с.

УДК 378.016:004.42

Ірина Мінтій

\section{ФОРМИ ОРГАНІЗАЦІЇ НАВЧАННЯ ДЛЯ ФОРМУВАННЯ КОМПЕТЕНТНОСТЕЙ 3 ПРОГРАМУВАННЯ}

Мінтій I. C. Форми організації навчання для формування компетентностей 3 програмування.

У статті розглянуто загальні форми організації навчання (фронтальні, групові, парні й індивідуальні) та певні види занять (лекція, лабораторна робота, консультація) для формування в майбутніх учителів інформатики компетентностей 3 програмування на прикладі модуля «Вступ до програмування» шкільного курсу інформатики.

Ключові слова:компетентнісний підхід, форми організації навчання; фронтальні, парні, групові, індивідуальні форми; лекція, лабораторна робота, консультація, самостійна робота.

Минтий И. С. Формы организации обучения для формирования компетентностей в программировании.

В статье рассмотрены общие формы организации обучения (фронтальные, 